\title{
Mergers and Acquisitions of Enterprises as a Tool for Increasing Value and Competitiveness: The case of Masan and Singha
}

\author{
Do Thi Ngoc Anh ${ }^{1}$, Elena Miroshina (Silantieva) ${ }^{2}$
}

\author{
1 International Finance Faculty, Financial University, Moscow; ngocanhdt102@gmail.com \\ ${ }^{2}$ Ph.D. in economics, Associate Professor, Department of World Economy and International Finance, Financial \\ University, Moscow; EAsila@yandex.ru
}

\section{Abstract}

The objective of this paper is to study the concept of mergers and acquisitions in the context of modern financial relations. It is an essential process nowadays for the growth and survival of almost all business. If any company is not adopting this way either they will not grow or will be acquired by the other major corporations. In this paper, to conduct a uniform research and arrive at an accurate conclusion why organizations take this innovative mode of expansion, we restrict our research to only Asian companies-Masan and Singha-which work in food and beverage industry. Over and above that, the main focus is on investigating the major issues associated with pre and post merging situations with special emphasis on the improvement of the business well-being and competitive edge.

Keywords: mergers; acquisitions; shareholders' wealth; food and beverage; Masan; Singha JEL Classification: D 23, G11, G34

I $\mathrm{n}$ the era of globalization and modernization, the wave of mergers and acquisitions (M\&A) is spreading with strong economic development in many countries. Several companies have used mergers and acquisitions as a way of enhancing their presence internationally and expanding their market share in new markets, especially in emerging ones. According to the analysis of economic experts, $M \& A$ is one of the solutions for the business restructure to improve efficiency. National economies are facing great opportunities in attracting foreign investment capital for industrialization and modernization. However, attracting foreign investment in traditional forms only is not enough for the current trend of foreign investment, especially the investment of transnational corporations from developed countries. Therefore, M\&A-the new form of investment-is an important legal foundation for investment, business and other services.

\section{A Conceptual Framework of Mergers and Acquisitions in the Modern Economy}

\section{The Theoretical Concept} of Mergers and Acquisitions

A merger or an acquisition refers to the combination of two or more companies into one new company or corporation. The method of execution points out the main difference between these two terms. Sherman and Hart (2006) define mergers as "...two companies joining together (usually through the exchange of shares) as peers to become one.” They define acquisitions as involving "...typically one company-the buyer-that purchases the assets or shares of the seller, with the form of payment being cash, the securities of the buyer, or other assets of value to the seller" (DePamphilis, 2017). The purpose of M\&A is to take control of the business to a certain degree rather than merely own a share of capital or shares of the business as small re- 
tail investors. Therefore, when an investor gains a stake in a business, the share of the business is sufficient to participate in deciding important issues of the business, then it can be considered as an M\&A activity. Conversely, when an investor owns a share of capital, but these shares are not sufficient to determine important issues of the enterprise, then it is only considered as a normal investment activity.

\section{Classifications of Mergers and Acquisitions in Business}

In general, there are three main types of merger and acquisition which are determined by different corporate strategies. They are categorized into horizontal, vertical and conglomerate. Horizontal integration is known for the practice of one business acquiring another company which is running the same product line, competing directly and sharing a unified market. Vertical integration is characterized by forwarding or backward integration along the supply chain. Conglomeration is characterized by the acquisition of unrelated companies that continue to produce in unrelated sectors. This section briefly introduces these three basic types of merger and acquisition.

\section{Horizontal merger and acquisition}

Horizontal integration is the merger and acquisition of firms in the same industry. It occurs between direct competitors manufacturing the same type of product and sharing the market. The result of this merger and acquisition brings opportunities to expand the market, increase efficiency in brand integration, reduce fixed costs and increase efficiency in the distribution system. For instance, the merger between JPMorgan and BankOne in the financial sector, or the largest merger in the banking sector between Algemene Bank Nederland $(\mathrm{ABN})$ and Amsterdamsche-Rotterdamsche Bank (AMRO) would be horizontal in nature.

\section{Vertical merger and acquisition}

Vertical integration is a merger between two enterprises located on the same value chain, leading to the forward or backward extension of the merged enterprise on that value chain.

This form of integration is divided into two subgroups:

(i) Forward merger: This occurs when an enterprise acquires its client enterprise, for example, a garment enterprise acquires a chain of retail clothing stores.

(ii) Backward merger: This happens when an enterprise acquires its suppliers, for example, a dairy production company acquires a packaging, bottling or dairy farming enterprise. Vertical consolidation allows enterprises to integrate the advantages of assuring and administrating the quality of goods or services, reducing the cost of intermediation, controlling the source of goods or output of competitors.

\section{Conglomerate merger and acquisition}

This approach is a link between businesses in different and irrelevant sectors of the economy, to reduce the risk fundamentally by diversification and to exploit different forms of economic activity in financial and resource sectors. Typically, businesses which want to diversify product ranges will choose the linking strategy for establishing the corporation.

Conglomerate mergers are divided into three groups:

(i) Pure Merger: This case happens where two businesses have no relationship with one another, for example, a medical device company purchases a fashion company.

(ii) Geographic expansion: Two enterprises produce the same product, but consumption in two markets is completely geographically isolated, for example, a restaurant in Hanoi buys a restaurant in Thailand.

(iii) Product Incorporation: Two companies produce two different types of products, but apply the same production or marketing technology, for example, a laundry detergent manufacturer buys an enterprise producing detergent hygiene.

\section{Mergers and Acquisitions as a Tool for Increasing Value and Competitiveness}

\section{Organizational and Economic Characteristics of Masan and Singha}

Masan Group Corporation is an investment holding company, manufactures, retails, and distributes food and beverage products in Vietnam (Masan Group Corp., 2018). The company manufactures and distributes a range of food and beverage products, including soya sauce, fish sauce, chilli sauce, instant noodles, instant coffee, instant cereals and bottled beverages. It also engages in breeding swine, providing animal pro- 
tein, and beer and beverage trading activities. The group was founded in 1996 and is headquartered in Ho Chi Minh City.

Singha is a member of Boon Rawd Brewery, the first and largest brewery in Thailand since 1933. The famous brands of this business are Singha, Leo, B-ing, Purra, Sanvo, Syder Bay, Boorward Farm, Pundee or Masita (Singha Corporation, nd). In addition to beer and non-alcoholic beverages, Singha is also known for its real estate, agriculture, food, restaurants, packaging and more than 50 member companies. Singha's current owner is billionaire Santi Bhirombhakdi, the ninth richest man in Thailand with total assets of $\$ 3.7$ billion (Forbes, 2017).

On December 25, 2015, Masan Group issued a press release on the M\&A deal with Singha from Thailand. Under a joint venture agreement, Singha will spend a total of $\$ 1.1$ billion to acquire a 25\% stake in Masan Consumer Holdings (Consumer Goods Company) and 33.3\% stake in Masan Brewery (Beverage Company). Among hundreds of M\&A deals in 2015, this was the deal that pushed the value of the Vietnamese M\&A market over the \$5-billion mark for the first time (Masan's history, 2017). Trade went into force in January 2016, it means that Masan's products would be available in the Thai kitchen, while Singha Asia's beverage would be in the living room of the Vietnamese. Both sides say that this relationship is unique because two companies of two ASEAN countries team up to develop cooperation. This combination allows Masan and Singha to expand their food and beverage markets to a regional scale, especially in the "ASEAN inland" countries (Vietnam, Thailand, Myanmar, Cambodia, Laos) with 250 million people. “To me, this means $1+1=5$," commented Nguyen Dang Quang, Masan Group chairman (Anh, 2015).

\section{Review of Masan-Singha Mergers-and- Acquisitions Deal as the Way to Increase Value and Competitiveness}

The phenomenon of Thai enterprises pouring money into the famous manufacturing enterprises of Vietnam has been strong in recent years. They do not only invest directly in Vietnam, but major Thai corporations also target the leading brands through mergers and acquisitions. Twenty years ago, Masan was known as an exporter of instant noodles and spices, but to the present time, it has been referred to as the largest producer of home-made consumer goods such as fish sauce, soy sauce, chilli sauce, convenience food, coffee, and meat products. According to statistics published by the group, "By the end of 2016, 98\% of Vietnamese households are using at least one Masan product.” Its net revenue in 2016 was approximately $\$ 2$ billion (Masan Group Corp., 2017).

On the one hand, Vietnam is considered as an attractive market for overseas investors. It is also a sign that Vietnam is becoming a processing and manufacturing centre of the world, as assessed by many leading experts in the industries. Nevertheless, the rapid fall of many of the top brands, many of which have a long history of development, may be a sign of regret. The rapid integration of Vietnam into the world economy opens many opportunities but also brings several challenges. Large international capital flows are ready to flow in, therefore, many leading Vietnamese business may become willing to sell their shares.

As in the case of Masan and Singha, cooperation means expanding the market for both parties. By working with Masan as a strategic partner, Singha can take advantage of Masan's strong distribution platform to reach the fast-growing market of more than 90 million Vietnamese customers. This partnership is a new opportunity for Singha to penetrate Vietnam's food and beverage industry, after its unsuccessful bidding effort for Vietnam's largest beer producer Sabeco (short form of the Saigon Beer, Alcohol and Beverage Corporation), as Sabeco said that it would not sell large minority shares to foreign companies. In return, Masan will benefit from a strong operating platform including deep distribution, understanding of local preferences, branding and manufacturing excellence. Masan's brand has a chance to spread widely as 69 million Thai consumers have a keen interest in sauce and coffee-the main products of the company. Within a year after Singha's first investment, Masan launched Chin-su Yod Thong fish sauce in Thailand market after a research and investigation to find the essence of Thai fish sauce. This event not only illustrates the comprehensive cooperation of the two leading corporations in Vietnam and Thailand in order to establish a regional platform of regional scale in the ASEAN market but also represents the first step of the journey to spread the culinary culture of the East to the world, with the flavour of fish sauce.

Based on an independent survey, 95\% of Thai consumers and chefs claimed that they liked and wanted to purchase Chin-su Yod Thong, of which, 
Table 1

Summary of MSN's H1 2016 P\&L

\begin{tabular}{lcccc}
\hline \multicolumn{1}{c}{ H1 2016 (VND billion) } & F\&B & Animal protein & Mining, banking \& others & Group total \\
\hline Revenue & 6,345 & 11,051 & 1,745 & 19,141 \\
NPAT contribution before MI & 904 & 1,031 & 374 & 2,309 \\
Unallocated expenses & & & -829 \\
Group's NPAT before MI & & & 1,480 \\
Group's NPAT post MI & & Animal protein & Mining, banking \& others & Group total \\
\hline \multicolumn{1}{c}{ H1 2015 (VND billion) } & F\&B & 3,332 & 1,201 & 10,414 \\
\hline Revenue & 5,801 & 160 & -22 & 990 \\
NPAT contribution before MI & 852 & & & -317 \\
Unallocated expenses & & & & 673 \\
Group's NPAT before MI & & & 364 \\
Group's NPAT post MI & & & &
\end{tabular}

Source: MSN \& VCSC. Accessed 4 April 2018. http://www.vietnamadvisors.com/masan-firing-on-many-cylinders

Table 2

Summary of MSN's F\&B segment

\begin{tabular}{lccc}
\multicolumn{1}{c}{ F\&B segment } & H1 2016 & H1 2015 & YoY \% \\
\hline Seasonings & 2,356 & 2,257 & $4.4 \%$ \\
Convenience Foods & 1,823 & 2,037 & $-10.5 \%$ \\
Beverages \& others & 1,623 & 1,291 & $25.7 \%$ \\
Beer & 543 & 296 & $83.4 \%$ \\
Total & $\mathbf{6 , 3 4 5}$ & $\mathbf{5 , 8 8 1}$ & $\mathbf{7 . 9 \%}$ \\
\hline
\end{tabular}

Source: MSN \& VCSC. Accessed 4 April 2018. http://www.vietnamadvisors.com/masan-firing-on-many-cylinders.

75\% said that they would replace their current fish sauce with Chin-su Yod. In January 2016, after the first funding of Masan deals with Singha, Masan's stake increased from $77.8 \%$ to $96.7 \%$ (Masan Group Corp., 2017). Not only does Masan win the taste of Thai consumers, but it also gains a competitive advantage over domestic competitors such as Thaipreeda Group, UFC Food and Rayong Fish Sauce Industry Co., Ltd.

Masan Group had a strong financial position with a revenue of VND 19,141 billion as of H1 2016 compared to VND 10,414 billion as H1 2015, an increase of $83.8 \%$ (Table 1).

Masan Consumer bounced back in Q2 2016 to help F \&B segment achieve $7.9 \%$ revenue growth in H1 (Phat \& Dao, 2016). The Group's cash inflows were also boosted by the injection of VND 13.3 trillion from Singha Asia for equity stakes in $\mathrm{MCH}$ and MB, offset by increased stakes in Vinacafé, Vinh Hao, Proconco and Quang Ninh (Masan Group Corp., 2017).
Singha Group has five businesses, including beer, food and beverages, energy, real estate and logistics. Beer and real estate contribute major sales. Currently, there are about 100 companies under Singha Group, eight of which are involved in the food business. Food business generates about 20 percent of the group's total sales, with the expectation that it will rise to 35 percent over the next three years (Mcclatchy, 2016). Over the period from 2004 to 2016 , volume growth in the beer sector on an annual basis increased stably and gradually [Figure 1]. This reveals sustainable development and is on the back of intensive business activity levels among the sector's leading alcoholic drink players like Singha Corporation, ThaiBev and Asia Pacific Breweries.

In the Vietnamese and regional market, Singha-Masan will motivate both companies in the race with another major Thai beverage company, ThaiBev. Interestingly enough, on 18 December 2017, Vietnam Beverage (49\% owned indirectly by 


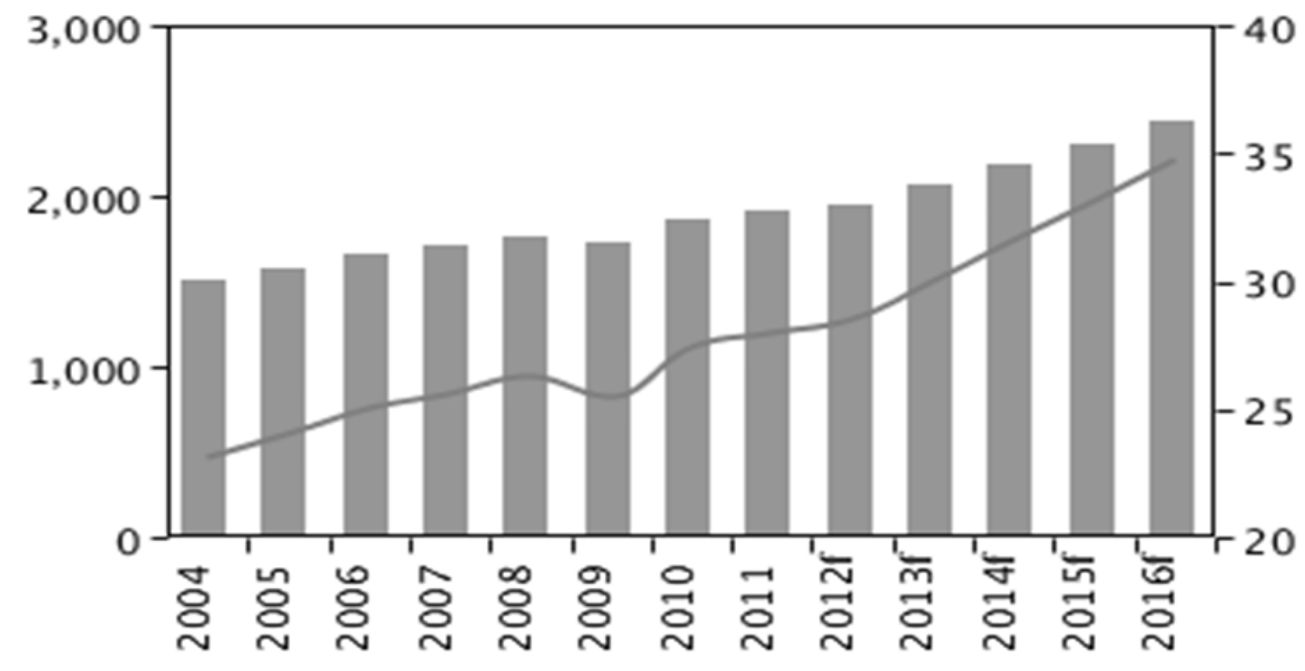

ALCOHOL: Beer Sales, mn litres (LHS)

ALCOHOL: Beer sales, litres per capita (RHS)

Figure 1. Thailand Beer Sales from 2004 to 2016 (LHS, RHS).

Source: BMI Research 2012 (Singha Investing, 2012). Retrieved from http://www.foodanddrinkinsight.com/company-newsalert-singha-investing-growth-nov-2012. Accessed 4 April 2018.

ThaiBev of Thai billionaire Charoen Sirivadhanabhakdi) bought a total of 343.66 million shares of Sabeco (Saigon Alcohol Beer and Beverages Corporation) at the price of 320,000 dong per share, equivalent to the total price worth nearly $\$ 5$ billion (ThaiBev finances, 2017). Vietnam Beverage officially owns the largest brewery in Vietnam. However, ThaiBev did borrow $\$ 5$ billion from banks to acquire Sabeco and had to pay for it within 24 months. ThaiBev will issue four tranches of long-term bonds in 2018 and 2019, the first in March 2015, with a target of 50 billion baht (Minh, 2018). While ThaiBev has to focus on promoting the efficiency of existing investments, especially making money to pay off debt, Singha-Masan can conquest the market by diversifying a lot of products to different regions.

Vietnam is the biggest market for beer in Southeast Asia and ranked third in Asia after Japan and China. It is also very competitive with high locality. In the north, there are Habeco and Halida; in the south, there is Sabeco; in the central, there are Larue and Huda. Foreign beer brands like Heineken, Tiger, Sapporo, and Carlsberg have been rooted in Vietnam for a long time, through joint ventures with local partners. In addition, there are a lot of Czech beer, German beer, Belgian beer, Japanese beer, American beer, Mexican beer... imported for sale. That is why, despite the potential market, Singha-Masan must make the most of their affiliation to wade into niche markets and compete with potential competitors.

\section{Conclusions}

Mergers and acquisitions are entered into for creating a win-win situation for all the concerned stakeholders of the company. In the long term, competition among food and beverage companies will become fiercer. Companies that have good quality products and prestige brands will survive and maintain their profits. Conversely, they may encounter financial difficulties and cannot increase the value of stakeholders. Due to this, the merger of Singha and Masan is a long-term venture of both companies, because, in this deal, they determined not to buy revenue, or profits for short-term purposes, but to buy the platform to serve their general strategy. Singha has advantages in production and experience in saving production costs, and with the strong distribution system of Masan, they will be a strong brand. Masan's experience has shown that in order to win the trust and love of the consumers, there must be a strong operational foundation made up of extensive distribution systems, knowledge of the consumers' habits, superior branding capabilities and excellence in production to satisfy consumer demand for quality and taste. Singha's product portfolio and operating platform can contribute to Masan's 
growth both in Vietnam and in the region. This is inextricably linked with Masan's desire to improve the material and spiritual life of consumers every day. As such, M\&A is an effective tool for both sides to realize their vision of serving the consumers, creating more value for shareholders, and generating more competitive advantages in the modern market.

\section{References}

Anh, Truong. (2015, 25 Dec). Thai brewery bought US \$ 1.1 billion stake in Masan. VietNam Finance. Retrieved from http://vietnamfinance.vn/hang-bia-thai-chi-11-ty-usd-mua-co-phan-masan-20151225141402858.htm.

DePamphilis, Donald. (2017). Mergers, Acquisitions, and Other Restructuring Activities. An Integrated Approach to Process, Tools, Cases, and Solutions. 9th Edition. Los Angeles, CA: Academic Press.

Forbes. (2017, May 31). Santi Bhirombhakdi \& family. Retrieved from https://www.forbes.com/profile/santi-bhirombhakdi.

Masan Group Corporation. (2017). Annual Report 2016. Retrieved from http://masangroup-cms-production.s3-apsoutheast-1.amazonaws.com/iblock/f4e/f4eeed6dc5ebc38c8ece082431282062/8edc091a62fd2736e4fc8fc24fceb2b4. PDF.

Masan's history of unique M\&A. (2017, 10 Aug). Vietnam Investment Review. Retrieved from http://www.vir.com.vn/ masans-history-of-unique-ma-51285.html.

Masan Group Corporation. (2018). Annual Report 2017. http://masangroup-cms-production.s3-ap-southeast-1.amazonaws.com/iblock/045/045200a3fbd88830b2044abc65dc2e3d/53290a2cb1cd776c7dce7cc01cfc67d7.pdf.

Mcclatchy, Tribune. (2016, 26 Sept). Singha earmarks 4.8B baht for Southeast Asian hub. Business Mirror. Retrieved from https://businessmirror.com.ph/singha-earmarks-4-8b-baht-for-southeast-asian-hub.

Minh, Quang. (2018, 26 Feb). Spending money to buy Sabeco. ThaiBev must make money to repay. Bizlive. Retrieved from http://bizlive.vn/kinh-doanh/do-tien-mua-sabeco-thaibev-phai-xoay-tien-tra-no-3436941.html. Accessed 04.04.2018.

Phat, Dang, \& Dao, Nguyen. (2016, 26 Aug). Masan Firing on Many Cylinders. VietNam Advisors. Retrieved from http://www.vietnamadvisors.com/masan-firing-on-many-cylinders. Accessed 04.04.2018.

Singha Corporation. http://www.singha.com. Accessed 04.04.2018.

Singha Investing For Growth. (2012, Nov). Food and Drink Insight. Retrieved from http://www.foodanddrinkinsight.com/ company-news-alert-singha-investing-growth-nov-2012. Accessed 04.04.2018.

ThaiBev finances Sabeco acquisition from loans. (2017, 30 Dec). Vietnam Investment Review. Retrieved from http://www. vir.com.vn/thaibev-finances-sabeco-acquisition-from-loans-55151.html. Accessed 04.04.2018.

Слияния и поглощения предприятий как инструмент повышения стоимости и конкурентоспособности на примере компаний Масан и Синга

До Тхи Нгок Ань' ${ }^{1}$ Елена Мирошина

\footnotetext{
${ }^{1}$ Международный финансовый факультет, Финансовый университет, Москва, Россия; ngocanhdt102@gmail.com

${ }^{2}$ К.э.н., доцент, Департамент мировой экономики и мировых финансов, Финансовый университет, Москва, Россия; EAsila@yandex.ru
}

\section{Аннотация}

Цель этой статьи - изучить концепцию слияний и поглощений в контексте современных финансовых отношений. В настоящее время это важный процесс для роста и выживания практически всех предприятий. Если компании не принимают такой способ, либо они не будут расти, или будут приобретены другими крупными корпорациями. В целях получения точного вывода, почему организации используют этот инновационный способ расширения, авторы ограничили исследование только азиатскими компаниями Масан и Синга, которые работают в пищевой промышленности и производстве напитков. Помимо этого, основное внимание уделяется изучению основных вопросов, связанных с ситуациями до и после слияния, с особым упором на улучшение благосостояния бизнеса и конкурентное преимущество.

Ключевые слова: слияния; поглощения; богатство акционеров; продукты питания; напитки; Масан; Синга 